\title{
Two opposite cases of metal accumulation in ria sediments: Ferrol and Corme-Laxe (Galicia, NW Iberian Peninsula)
}

\section{Dos casos opuestos en la acumulación de metales en el sedimento de una ría: Ferrol y Corme-Laxe (Galicia, NO Península Ibérica)}

\author{
Antonio Cobelo-García* \\ Ana Labandeira \\ Ricardo Prego
}

\author{
Grupo de Biogeoquímica Marina \\ Instituto de Investigaciones Marinas (CSIC) \\ Eduardo Cabello 6 \\ E-36208 Vigo, España \\ * E-mail: acobelo@iim.csic.es
}

Recibido en junio de 2003 ; aceptado en febrero de 2005

\begin{abstract}
The accumulation of heavy metals $(\mathrm{Cd}, \mathrm{Cu}, \mathrm{Pb}$ and $\mathrm{Zn})$ in surface sediments $(<63 \mu \mathrm{m})$ of the Ferrol and Corme-Laxe rias was studied. These two rias have opposite characteristics from the point of view of both the morphology and the anthropogenic impact. Low metal concentrations were found in the Corme-Laxe Ria, with the highest values observed in the Anllóns River estuary, probably due to a higher lithogenic composition of the sediments. Concentrations in the Corme-Laxe Ria (Cd, $0.10 \pm$ $0.03 \mu \mathrm{g} \mathrm{g}^{-1}$; Cu, $5 \pm 2 \mu \mathrm{g} \mathrm{g}^{-1}$; Pb, $12 \pm 4 \mu \mathrm{g} \mathrm{g}^{-1}$; and $\mathrm{Zn}, 49 \pm 17 \mu \mathrm{g} \mathrm{g}^{-1}$ ) can be used as a good reference for metal background values for sediments from the 18 Galician rias. Although these background values are lower than those previously reported for the Galician coast, they are similar to those found in other uncontaminated coastal and marine systems. The highest concentrations for Ferrol were generally found in the middle part of the ria, which receives the most important urban and industrial impact. The values obtained show evident metal contamination in the middle and inner parts of the Ferrol Ria, with enrichment factors of 4-10 for $\mathrm{Cd}$, 5 for $\mathrm{Cu}, 2-3$ for $\mathrm{Pb}$ and 4-5 for $\mathrm{Zn}$.
\end{abstract}

Key words: heavy metals, contamination, sediments, background values, Ferrol, Corme-Laxe, Galicia.

\section{Resumen}

Se estudió la acumulación de metales pesados ( $\mathrm{Cd}, \mathrm{Cu}, \mathrm{Pb}$ y $\mathrm{Zn})$ en el sedimento $(<63 \mu \mathrm{m})$ superficial en las rías de Ferrol y Corme-Laxe, las cuales poseen características contrapuestas tanto desde el punto de vista de su morfología como de su influencia urbana e industrial. La ría de Corme-Laxe presentó bajos niveles de metales en los sedimentos, siendo mayores en el estuario del Río Anllóns probablemente debido a un mayor grado litogénico de los sedimentos. Las concentraciones obtenidas en la ría de Laxe $\left(0.10 \pm 0.03 \mu \mathrm{g} \mathrm{g}^{-1}\right.$ de Cd, $5 \pm 2 \mu \mathrm{g} \mathrm{g}^{-1}$ de Cu, $12 \pm 4 \mu \mathrm{g} \mathrm{g}^{-1}$ de $\mathrm{Pb}$ y $49 \pm 17 \mu \mathrm{g} \mathrm{g}^{-1}$ de $\left.\mathrm{Zn}\right)$ resultan una buena referencia de valores naturales de fondo para metales en las 18 rías gallegas. Aunque éstos son menores a otros considerados para la costa gallega, son similares a los medidos a nivel mundial en sedimentos marinos no contaminados. En Ferrol, las máximas concentraciones de metales se presentan generalmente en la parte media de la ría, donde se localiza el mayor núcleo de población y buena parte de la actividad industrial. Los datos allí obtenidos señalan la existencia de una evidente contaminación metálica en la parte media e interna de la ría de Ferrol con factores de enriquecimiento comprendidos entre 4-10 para Cd, 5 para Cu, 2-3 para Pb y 4-5 para Zn.

Palabras clave: metales pesados, contaminación, sedimentos, valores de fondo, Ferrol, Corme-Laxe, Galicia.

\section{Introduction}

Sediments play a key role in the biogeochemical cycles of metals, providing useful information on their inputs to coastal and marine systems (Zwolsman et al., 1996). Accordingly, sediments can help us to localize the contamination sources in the estuarine-coastal zone, where industrial and urban effluents are usually dumped. The sediments of estuaries and rias act as

\section{Introducción}

El compartimiento biogeoquímico del sedimento es muy importante para el conocimiento del ciclo de los metales pesados ya que proporciona información sobre su entrada a los ecosistemas (Zwolsman et al., 1996). Por ello, el registro sedimentario ofrece un buena ayuda a la hora de localizar las fuentes de contaminación en los ambientes estuárico-costeros 
a sink for the metals released into the coastal zone (Millward and Glegg, 1997; Balci, 1999; Helland, 2001).

About $40 \%$ of the Galician population lives close to the rias and an important fraction of the total industrial activity is located along their margins, leading to an evident risk of contamination in these environments (Cobelo-García et al., 2004). Hence, information on metal concentrations in a pristine ria that can be used as reference for those anthropogenically impacted is needed. The morphology must also be taken into account because of the critical role it may have in the accumulation of metals and other contaminants within the ria. No such studies, however, have been carried out to date (Prego and Cobelo-García, 2003).

The Ferrol Ria supports a population of 143,000 inhabitants distributed in the towns of Ferrol, Fene, Mugardos, Neda and Narón. Fene and Farrol are important industrial areas, including brick manufacturing, wood and milk products, polypropylene, iron and steel, and shipyard activities, and have a busy commercial port with a vessel trade of around $1,500,000$ tons per year, transporting goods such as dunite, coal, scrap iron, wood, and iron and steel products (Lueiro and Prego, 1999). On the other hand, the Corme-Laxe Ria is completely different from the Ferrol Ria in regard to anthropogenic impact. A population of only 18,100 inhabitants is settled along its margin - towns of Laxe, Cabana and Ponteceso-and the industrial activity is very scarce, fishing and farming being the main activities.

Both rias (fig. 1), situated $50 \mathrm{~km}$ apart, are suitable for a morphological comparison because they have similar dimensions and the same mean depth (table 1). The Ferrol Ria, however, is a semi-enclosed embayment connected to the ocean by a narrow channel (0.35 km wide and $2 \mathrm{~km}$ long), whereas the Corme-Laxe Ria has a wide mouth through which potential contaminants are supposedly washed out by the sea. The fluvial discharges are also different (table 1), favouring water renewal (Prego and Fraga, 1992) in the Corme-Laxe Ria as opposed to the Ferrol Ria.

From a lithological standpoint they are quite similar since both watersheds are formed by igneous rocks. The Ferrol Ria and its adjacent watersheds are dominated by schists and gneisses, while the Corme-Laxe Ria and the Anllóns River are dominated by schists, gneisses and granites (Carballeira et al., 2000).

These two rias are therefore useful for a comparative study on metal accumulation in the sediments. The main objectives of the present study are (i) to ascertain the state of metal contamination in the Ferrol Ria in relation to the Corme-Laxe Ria and (ii) to establish the values found in the Corme-Laxe Ria as backgound reference for the rest of the rias.

\section{Material and methods}

Sediment samples were taken at 16 sampling sites in the Ferrol Ria (September 1998) and at 13 sites in the Corme-Laxe Ria (July 2000), from the R/V CSIC Mytilus and its auxiliary boat Zoea. Stations are indicated in figure 1. desde donde pueden verterse cantidades considerables de productos de desechos urbanos e industriales. Así, dichos estuarios actuan como receptores y sumideros de los metales vertidos a los sistemas costeros (Millward y Glegg, 1997; Balci, 1999; Helland, 2001).

En Galicia, 40\% de la población vive cerca del litoral de las rías y gran parte de sus áreas industrializadas se encuentran en sus márgenes, conduciendo, entre otros, a un evidente riesgo de contaminación metálica en estos ecosistemas propios del noroeste de la Península Ibérica (Cobelo-García et al., 2004). Por esta razón, se requiere información sobre las concentraciones de metales en una ría prístina como valores de referencia para las rías que han sido impactadas antropogénicamente. También es importante tomar en consideración la morfología de las rías, ya que esta juega un papel crucial en la acumulación de metales y otros contaminantes en estos cuerpos de agua. Sin embargo, hasta la fecha no se han llevado a cabo este tipo de estudios (Prego y Cobelo-García, 2003).

Un claro ejemplo de ello es la ría de Ferrol que concentra una población de 143,000 habitantes repartidos principalmente en los municipios de Ferrol, Fene, Mugardos, Neda y Narón. También soporta actividad industrial con derivados de la madera y lácteos, polipropileno, siderurgia y fabricación de ladrillos, junto con diversos astilleros situados en Fene y Ferrol y un importante puerto comercial con un tráfico de buques sobre 1,500,000 toneladas brutas de registro anuales que mueven principalmente mineral de dunita, carbón, chatarra, madera y productos siderúrgicos (Lueiro y Prego, 1999).

La ría de Ferrol es una ría cerrada, conectada al océano mediante un canal angosto $(0.35 \mathrm{~km}$ de ancho y $2 \mathrm{~km}$ de largo, fig. 1), que termina en una boca estrecha y poco profunda (tabla 1). La ría de Corme-Laxe se puede considerar en el extremo opuesto a la de Ferrol en cuanto a influencias antropogénicas. La población asentada sobre sus márgenes es únicamente de 18,100 habitantes, pertenecientes a los municipios de Laxe, Cabana y Ponteceso, y la actividad industrial que soporta es muy escasa, dedicándose más bien a tareas agropecuarias y pesqueras.

Ambas rías, distantes entre sí $~ 50 \mathrm{~km}$, son adecuadas para una comparación morfológica pues poseen dimensiones similares y una misma profundidad media (tabla 1). La ría de Ferrol es, no obstante, más elongada, mientras que la de Corme-Laxe es de boca abierta y más profunda y, consecuentemente, la ría de Corme-Laxe debe estar mucho más lavada por el océano que la de Ferrol. También los caudales de los ríos que desembocan en sus cabeceras son diferentes (tabla 1), lo que debe favorecer la renovación del agua (Prego y Fraga, 1992) en la ría de Corme-Laxe.

En cuanto a sus litologías, éstas son bastante parecidas pues ambas cuencas están formadas por rocas ígneas. La ría de Ferrol y sus cuencas fluviales adyacentes están dominadas por esquistos y rocas gnéisicas, mientras que Corme-Laxe y el Río Anllóns presentan un panorama más complejo, con esquistos, gneises y granitos (Carballeira et al., 2000).

Estas dos rías, por lo tanto, sirven para un estudio comparativo de la acumulación de metales pesados en los sedimentos 


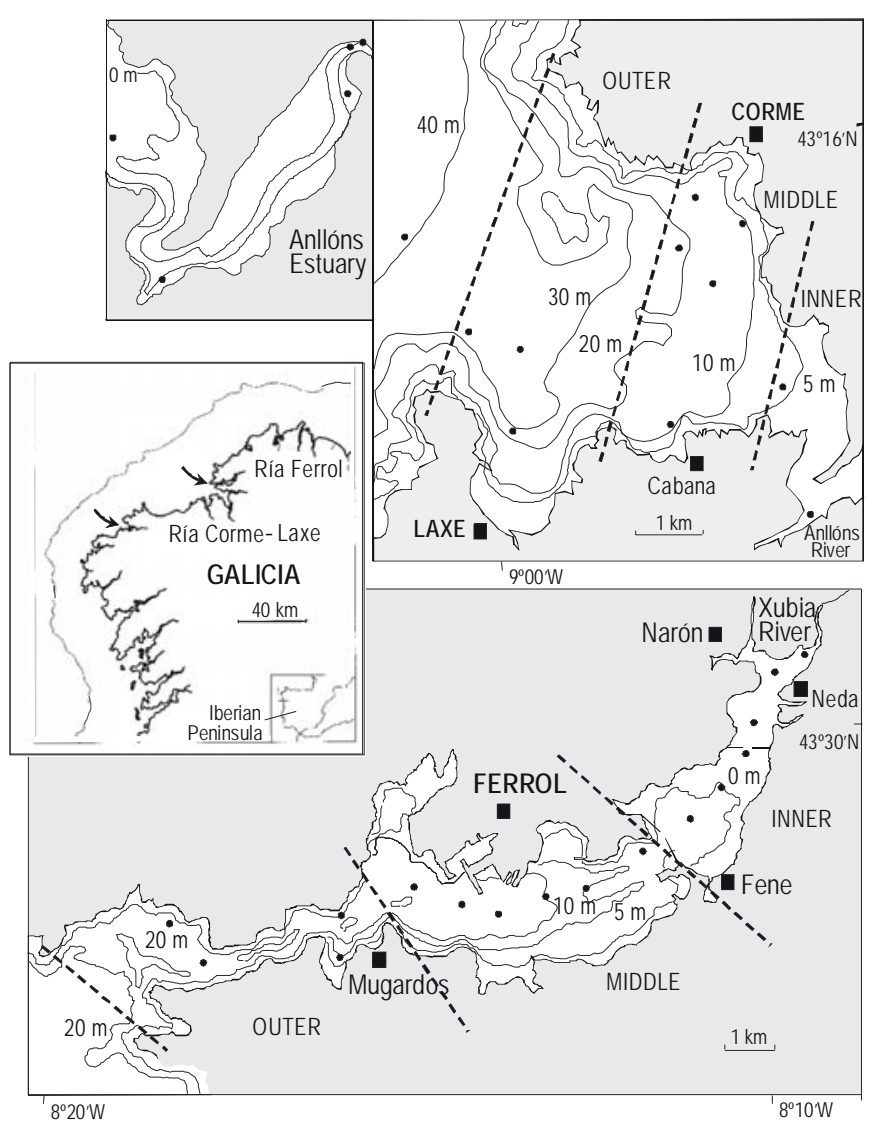

Figure 1. Corme-Laxe and Ferrol rias (NW Iberian Peninsula), showing the bathymetry and sampling sites.

Figura 1. Rías de Corme-Laxe y Ferrol con su batimetría, zonas y puntos de muestreo.

Two Van Veen grab samplers of different size were used. Only the surface layer of the sediment was collected $(<1 \mathrm{~cm})$, using polyethylene (PE) spatulas, and stored in hermeticallyclosed PE vials (previously acid-washed with $\mathrm{HNO}_{3} 10 \%$ ) and kept in a cooler at $4^{\circ} \mathrm{C}$; samples were later dried in an oven $\left(\leq 50^{\circ} \mathrm{C}\right)$. Once dried, sediments were sieved in order to get the fine fraction $(<63 \mu \mathrm{m})$.

The determination of $\mathrm{Cd}, \mathrm{Pb}$ and $\mathrm{Cu}$ was carried out by direct injection of sediment slurries (Bermejo-Barrera et al., 1994), using electro-thermal atomic absorption spectrometry (ET-AAS) with a Zeeman background correction Varian 220 apparatus; Zn was determined by means of flame (airacetylene) atomic absorption spectrometry (FAAS), using a Perkin-Elmer 2380 after digestion of the samples. Samples que sirva al doble objetivo del presente artículo: conocer el estado de contaminación metálica en la ría de Ferrol con relación a la de Corme-Laxe y la utilidad de esta última como referencia para las demás rías.

\section{Material y métodos}

Las muestras de sedimento fueron recogidas en 16 puntos de la ría de Ferrol (septiembre de 1998) y 13 de la de CormeLaxe (julio de 2000) desde el B/I CSIC Mytilus y su embarcación auxiliar Zoea en la estaciones señaladas en la figura 1.

Se utilizaron dos dragas tipo Van Veen con diferente tamaño y del material extraído se tomaron muestras únicamente de la capa superficial de $1 \mathrm{~cm}$ de espesor con una espátula de polietileno, guardándose en viales del mismo material (previamente lavados con $\mathrm{HNO}_{3}$ 10\%) herméticamente cerrados y almacenados en nevera a $4^{\circ} \mathrm{C}$ hasta el momento de su secado en estufa $\left(\leq 50^{\circ} \mathrm{C}\right)$. Luego el sedimento se tamizó para obtener la fracción a analizar $(<63 \mu \mathrm{m})$.

La determinación de $\mathrm{Cd}$, $\mathrm{Pb}$ y Cu se llevó a cabo mediante la inyección directa de suspensiones de sedimento (BermejoBarrera et al., 1994) utilizando la espectrometría de absorción atómica con atomización electro térmica mediante un equipo Varian 220 con corrección de fondo Zeeman. Para la determinación de Zn se digirieron las muestras en bombas de teflón con una mezcla de $\mathrm{HNO}_{3}$ al $65 \%$ y $\mathrm{HF}$ al $48 \%$ dentro de un horno de microondas (Milestone 1200 Mega) de acuerdo con la norma EPA 3052 (EPA, 1996) para sedimentos de tipo silíceo. El posterior análisis de la muestra se realizó con un equipo de espectrometría de absorción atómica con atomización en llama de aire-acetileno (Perkin-Elmer 2380).

El procedimiento analítico fue verificado utilizando dos materiales certificados de referencia: PACS-l y PACS-2. Se obtuvo una buena concordancia con los valores certificados: $409 \pm 24 \mu \mathrm{g} \mathrm{g}^{-1}$ de Pb y $424 \pm 37 \mu \mathrm{g} \mathrm{g}^{-1}$ de Cu frente a los del PACS-l, $404 \pm 20 \mu \mathrm{g} \mathrm{g}^{-1}$ de Pb y $452 \pm 16 \mu \mathrm{g} \mathrm{g}^{-1}$ de Cu. Por otra parte, se obtuvieron $2.14 \pm 0.09 \mu \mathrm{g} \mathrm{g}^{-1} \mathrm{de}^{\mathrm{Cd}}$ y $360 \pm 2 \mu \mathrm{g} \mathrm{g}^{-1} \mathrm{de}$ Zn frente a los valores certificados de PACS-2, $2.11 \pm 0.15$ $\mu \mathrm{g} \mathrm{g}^{-1}$ de Cd y $364 \pm 23 \mu \mathrm{g} \mathrm{g}^{-1}$ de Zn, respectivamente.

\section{Resultados}

Los resultados de los análisis fueron promediados de acuerdo con la división hecha en ambas rías, Ferrol y CormeLaxe, en parte interna o estuárica, parte media o ría en sí y parte externa, de clara influencia oceánica. Se consideraron

Table 1. General dimensions of the Corme-Laxe and Ferrol rias and fresh-water discharges.

Tabla 1. Dimensiones de las rías de Corme-Laxe y Ferrol y contribuciones fluviales.

\begin{tabular}{lcccccccc}
\hline & $\begin{array}{c}\text { Length } \\
(\mathrm{km})\end{array}$ & $\begin{array}{c}\text { Extension } \\
\left(\mathrm{km}^{2}\right)\end{array}$ & $\begin{array}{c}\text { Volume } \\
\left(\mathrm{hm}^{3}\right)\end{array}$ & $\begin{array}{c}\text { Mean depth } \\
(\mathrm{m})\end{array}$ & $\begin{array}{c}\text { Depth at mouth } \\
(\mathrm{m})\end{array}$ & $\begin{array}{c}\text { Width at mouth } \\
(\mathrm{km})\end{array}$ & River & $\begin{array}{c}\text { Fresh-water discharge } \\
\left(\mathrm{m}^{3} \mathrm{~s}^{-1}\right)\end{array}$ \\
\hline Corme-Laxe & 6 & 27 & 380 & 14 & 36 & 4.9 & Anllóns & 11.4 \\
Ferrol & 15 & 21 & 290 & 14 & 25 & 2.3 & Xubia & 5.5 \\
\hline
\end{tabular}


were microwave (Milestone 1200 Mega) digested in Teflon bombs using a $\mathrm{HNO}_{3} 65 \%$ and $\mathrm{HF} 48 \%$ mixture following the EPA 3052 guideline (EPA, 1996) for siliceous-type sediments.

The accuracy of the analytical procedure was checked using two certified reference materials: PACS-l and PACS-2. A good agreement was found between the values obtained and the certified concentrations: $409 \pm 24 \mu \mathrm{g} \mathrm{g}^{-1}(\mathrm{~Pb})$ and $424 \pm$ $37 \mu \mathrm{g} \mathrm{g}^{-1}(\mathrm{Cu})$ vs the PACS-l certified values of $404 \pm 20 \mu \mathrm{g} \mathrm{g}^{-1}$ $(\mathrm{Pb})$ and $452 \pm 16 \mu \mathrm{g} \mathrm{g}^{-1}(\mathrm{Cu})$; and $2.14 \pm 0.09 \mu \mathrm{g} \mathrm{g}^{-1}(\mathrm{Cd})$ and $360 \pm 2 \mu \mathrm{g} \mathrm{g}^{-1}(\mathrm{Zn}) v \mathrm{~s}$ the PACS-2 certified concentrations of $2.11 \pm 0.15 \mu \mathrm{g} \mathrm{g}^{-1}(\mathrm{Cd})$ and $364 \pm 23 \mu \mathrm{g} \mathrm{g}^{-1}(\mathrm{Zn})$.

\section{Results}

Average results for the different areas-inner (estuarine), middle and outer-of the Ferrol and Corme-Laxe rias are indicated in table 2. From five to six sampling sites were considered for the inner and middle areas, and from three to four for the outer ria.

The Cd concentrations in the Ferrol Ria decreased seawards, ranging from $0.2 \mu \mathrm{g} \mathrm{g}^{-1}$ in the outer area to $1.8 \mu \mathrm{g} \mathrm{g}^{-1}$ in the inner part. The Corme-Laxe Ria showed a similar trend but with lower Cd concentrations, ranging from $0.3 \mu \mathrm{g} \mathrm{g}^{-1}$ in the estuary to around $0.1 \mu \mathrm{g} \mathrm{g}^{-1}$ in the rest of the ria.

The highest $\mathrm{Cu}$ concentrations in the Corme-Laxe Ria were found at its head, reaching values of up to $49 \mu \mathrm{g} \mathrm{g}^{-1}$, with a sixfold decrease towards the middle and outer areas (table 2). In Ferrol, the highest values were obtained in the inner and middle parts, with an average of 58 and $66 \mu \mathrm{g} \mathrm{g}^{-1}$, respectively, but with a high dispersion of data in the latter case (table 2); the $\mathrm{Cu}$ values in the outer ria were around three times lower.

The $\mathrm{Pb}$ concentrations in Corme-Laxe decreased from the estuarine area towards the middle and outer parts, from mean values of around 30 to $12 \mu \mathrm{g} \mathrm{g}^{-1}$. Significantly higher values were obtained in Ferrol, with maximum concentrations in the middle ria $\left(75 \pm 21 \mu \mathrm{g} \mathrm{g}^{-1}\right)$ that are three times higher than the values found at the mouth (table 2).

The distribution of $\mathrm{Zn}$ in Ferrol was similar to that of $\mathrm{Cu}$ and $\mathrm{Pb}$ : the highest concentrations $\left(267 \pm 43 \mu \mathrm{g} \mathrm{g}^{-1}\right)$ were entre cinco y seis diferentes puntos de muestreo para las partes estuárica y media, y tres o cuatro para la externa. Los resultados se muestran en la tabla 2.

En Ferrol las concentraciones de $\mathrm{Cd}$ decrecieron hacia fuera de la ría y estuvieron comprendidas entre $0.2 \mu \mathrm{g} \mathrm{g}^{-1} \mathrm{en} \mathrm{su}$ parte externa y $1.8 \mu \mathrm{g} \mathrm{g}^{-1}$ en la interna. La ría de Corme-Laxe mostró un patrón semejante, pero con niveles más moderados de este metal $\left(0.3 \mu \mathrm{g} \mathrm{g}^{-1}\right.$ en su estuario y en torno a $0.1 \mu \mathrm{g} \mathrm{g}^{-1}$ en el resto de la ría).

La mayor presencia de $\mathrm{Cu}$ en Corme-Laxe se encontró en su cabecera, llegando hasta $49 \mu \mathrm{g} \mathrm{g}^{-1} \mathrm{y}$ decreciendo unas seis veces en las zonas media y externa (tabla 2). En ría de Ferrol, las mayores concentraciones de $\mathrm{Cu}$ estuvieron en las partes media e interna (66 y $58 \mu \mathrm{g} \mathrm{g}^{-1}$ en promedio) aunque en la interna se obtuvo un intervalo de valores grande (tabla 2); la concentración de $\mathrm{Cu}$ en la parte oceánica es una tercera parte menor.

El Pb en Corme-Laxe mostró concentraciones que disminuyeron de la parte estuárica hacia la media y la oceánica, desde valores medios de $\sim 30 \mu \mathrm{g} \mathrm{g}^{-1}$ hasta valores de $12 \mu \mathrm{g} \mathrm{g}^{-1}$. Los valores encontrados en Ferrol fueron ampliamente mayores y con sus valores máximos en la zona media $\left(75 \pm 21 \mu \mathrm{g} \mathrm{g}^{-1}\right)$, casi tres veces superiores a los encontrados en la boca de la ría (tabla 2).

$\mathrm{Al}$ igual que para el $\mathrm{Pb}$ y el $\mathrm{Cu}$, las máximas concentraciomes de $\mathrm{Zn}$ en la ría de Ferrol se midieron en su parte media $\left(267 \pm 43 \mu \mathrm{g} \mathrm{g}^{-1}\right)$ y fueron ligeramente superiores a los valores encontrados en su cabecera (tabla 2). Las concentraciones mínimas de Zn (115 $\left.\mu \mathrm{g} \mathrm{g}^{-1}\right)$, al igual que las de todos los metales analizados, se midieron en la parte externa y, como ocurrió para el $\mathrm{Cu}$, resultaron semejantes a las correspondientes a Corme-Laxe en su estuario. En el resto de esta ría, la concentración de Zn es cerca de la mitad (49 $\left.\mu \mathrm{g} \mathrm{g}^{-1}\right)$.

\section{Discusión}

Los sedimentos superficiales de la ría de Corme-Laxe presentan bajos contenidos de los metales $\mathrm{Cd}, \mathrm{Cu}, \mathrm{Pb}$ y $\mathrm{Zn}$, que siguen una pauta decreciente desde la cabecera de la ría hasta

Table 2. Concentrations of heavy metals $\left(\mu \mathrm{g} \mathrm{g}^{-1}\right)$ in the fine fraction $(<63 \mu \mathrm{m})$ of surface sediments $(<1 \mathrm{~cm})$ from the Corme-Laxe and Ferrol rias.

Tabla 2. Concentraciones de metales pesados $\left(\mu \mathrm{g} \mathrm{g} \mathrm{g}^{-1}\right)$ en la fracción fina $(<63 \mathrm{~mm})$ del sedimento superficial $(<1 \mathrm{~cm})$ de las rías de Corme-Laxe y Ferrol.

\begin{tabular}{llcccc}
\hline & Zone & {$[\mathrm{Cd}]$} & {$[\mathrm{Cu}]$} & {$[\mathrm{Pb}]$} & {$[\mathrm{Zn}]$} \\
\hline Corme-Laxe & Estuarine & $0.33 \pm 0.19$ & $29.2 \pm 19.1$ & $30.4 \pm 15.2$ & $110 \pm 25$ \\
& Middle & $0.10 \pm 0.04$ & $4.8 \pm 2.1$ & $27.5 \pm 26.3$ & $49.4 \pm 19.2$ \\
& Outer & $0.09 \pm 0.01$ & $5.4 \pm 2.4$ & $12.4 \pm 4.0$ & $49.4 \pm 17.1$ \\
\hline Ferrol & Estuarine & $1.00 \pm 0.80$ & $57.7 \pm 40.1$ & $47.5 \pm 13.0$ & $235 \pm 54$ \\
& Middle & $0.38 \pm 0.15$ & $65.5 \pm 16.8$ & $75.5 \pm 21.2$ & $267 \pm 43$ \\
& Outer & $0.23 \pm 0.06$ & $20.1 \pm 7.1$ & $27.9 \pm 15.4$ & $115 \pm 5$ \\
\hline
\end{tabular}


found in the middle ria and were more than two times higher than at the mouth (table 2), where the lowest values were found $\left(115 \pm 5 \mu \mathrm{g} \mathrm{g}^{-1}\right)$. The $\mathrm{Zn}$ concentrations in the outer Ferrol Ria, like those of $\mathrm{Cu}$, were similar to those found in the estuarine area of the Corme-Laxe Ria. In the middle and outer parts of this ria, the $\mathrm{Zn}$ concentrations were considerably lower, $49 \mu \mathrm{g} \mathrm{g}^{-1}$ (table 2).

\section{Discussion}

Low $\mathrm{Cd}, \mathrm{Cu}, \mathrm{Pb}$ and $\mathrm{Zn}$ concentrations were observed in the surface sediments of the Corme-Laxe Ria, following a decreasing trend from the head towards the mouth. The relatively higher concentrations obtained in the Anllóns River estuary are largely due to the higher lithogenic composition of the sediment, deposited by the river, which is enriched in metals compared to the ocean-borne particulate matter (Labandeira, 2003). Other factors, such as contamination inputs throughout the estuary, may also play a role in the concentrations found. Outside the estuarine area (beyond the sandy bar, fig. 1), $\mathrm{Cu}$ and $\mathrm{Zn}$ concentrations were similar in both the middle and outer ria (table 2). The exception was $\mathrm{Pb}$, whose concentration in the middle ria was similar-with a high dispersion of data- to that found in the estuary.

If the average $\mathrm{Cd}, \mathrm{Cu}, \mathrm{Zn}$ and $\mathrm{Pb}$ concentrations found in the middle and outer parts of the Corme-Laxe Ria are compared with the background values reported for the Galician rias, with typical values for the lithosphere or with uncontaminated coastal and marine sediments (table 3), it is evident that the values recorded in Corme-Laxe are lower than those previously reported for the Galician rias (Carral et al., 1995; Carballeira et al., 2000; Cobelo-García and Prego, 2003). On the other hand, these values are similar to those reported for other uncontaminated coastal systems or the lithosphere (table 3). Therefore, Corme-Laxe can be considered a non- su boca. Las mayores concentraciones encontradas en el estuario del Río Anllóns se deben en gran medida a la mayor fracción litogénica del sedimento-que es depositada por el río-y que es más rica en metales (Labandeira, 2003). Otros factores, como la existencia de pequeños focos de contaminación en el estuario, pueden también estar influyendo en dichas concentraciones. Fuera de la parte estuárica de la ría, definida hasta la barra arenosa (fig. 1), los niveles de Cu y Zn son semejantes en el sedimento tanto en su parte media como en la externa, tabla 2. La excepción son los valores de Pb obtenidos en la zona media, los cuales son semejantes a los medidos en el estuario y con un amplio intervalo de variación.

$\mathrm{Si}$ se comparan las concentraciones medias de $\mathrm{Cd}, \mathrm{Cu}, \mathrm{Zn}$ y $\mathrm{Pb}$ medidas en las partes media y externa de la ría de CormeLaxe con los valores reportados como naturales para las rías gallegas, los de litosfera y los de sedimentos marinos estuáricos no contaminados (tabla 3) se observa que los valores registrados en Corme-Laxe son más bajos que los valores metálicos de fondo reportados hasta el momento para las rías gallegas (Carral et al., 1995; Carballeira et al., 2000; CobeloGarcía y Prego, 2003). Por otra parte, estos valores son comparables a las concentraciones encontradas en otras zonas costeras no contaminadas o en la litosfera (tabla 3). Por tanto, la ría de Corme-Laxe puede ser considerada una ría no contaminada. Consecuentemente, los datos aquí presentados pueden servir como valores de fondo o de referencia del contenido natural de esos cuatro metales en los sedimentos de las rías a la hora de estudiar su estado de contaminación. Además, el reportado aquí es el primer valor de fondo propuesto para el Cd en la región de las rías gallegas.

En la ría de Ferrol, a excepción del Cd, las máximas concentraciones fueron encontradas en su parte media (tabla 2), donde se encuentra asentado el mayor núcleo de población y buena parte de la actividad industrial. De acuerdo con los valores de fondo propuestos para esta ría (Cobelo-García y Prego,

Table 3. Background values reported for the Galician coast and the lithosphere, and for uncontaminated coastal and marine sediments (UCMS). Tabla 3. Niveles de fondo establecidos para la costa gallega, la litosfera y concentraciones en sedimentos marinos no contaminados (UCMS).

\begin{tabular}{|c|c|c|c|c|c|c|}
\hline & & [Cd] & {$[\mathrm{Cu}]$} & {$[\mathrm{Pb}]$} & {$[\mathrm{Zn}]$} & Reference \\
\hline \multirow{3}{*}{ Galicia } & Schist/gneiss & --- & 35 & 50 & 120 & Carballeira et al. (2000) \\
\hline & General & --- & 28 & 53 & 122 & Carral et al. (1995) \\
\hline & Ferrol Ria & --- & $12 \pm 3$ & $27 \pm 7$ & $55 \pm 11$ & Cobelo-García \& Prego (2003) \\
\hline Corme-Laxe Ria & & $0.10 \pm 0.03$ & $5 \pm 2$ & $12 \pm 4$ & $49 \pm 18$ & This study \\
\hline \multirow[t]{3}{*}{ UCMS } & Gulf of Saros, NE Aegean Sea & --- & $19 \pm 9$ & $22 \pm 15$ & $73 \pm 32$ & Sari \& Cagatay (2001) \\
\hline & Chuckhi Sea, Alaska & --- & $17 \pm 6$ & -- & $61 \pm 22$ & Naidu et al. (1997) \\
\hline & Cleveland Bay, Australia & $0.020 \pm 0.005$ & $6 \pm 1$ & $9 \pm 1$ & $24 \pm 2$ & Doherty et al. (2000) \\
\hline
\end{tabular}


contaminated ria. Accordingly, the metal concentrations presented herein can be used as reference or background values to study metal contamination in other Galician rias. Moreover, the Cd concentrations reported here constitute the first background values given for the Galician coastal system.

With the exception of $\mathrm{Cd}$, the highest concentrations in the Ferrol Ria were found in the middle part (table 2), where most of the population and the industrial activities are settled. Using the background values reported for this ria (Cobelo-García and Prego, 2003; table 3), the metal contamination can be estimated using the enrichment factors (EF; Hakanson, 1980), defined as: $\mathrm{EF}=\mathrm{CV} / \mathrm{BV}$, where $\mathrm{CV}$ represents the current value observed and $\mathrm{BV}$ the background value. Accordingly, $\mathrm{Cu}$ contamination is considerable $(3<\mathrm{EF}<6)$ in the inner and middle ria $\left(\mathrm{EF}_{\mathrm{Cu}}=4.8 \pm 3.3\right.$ and $5.5 \pm 1.4$, respectively) and moderate $(1<\mathrm{EF}<3)$ in the outer part $\left(\mathrm{EF}_{\mathrm{Cu}}=1.7 \pm 0.6\right)$, while $\mathrm{Pb}$ contamination is moderate in the inner $\left(\mathrm{EF}_{\mathrm{Pb}}=1.8 \pm\right.$ $0.5)$ and the middle ria $\left(\mathrm{EF}_{\mathrm{Pb}}=2.8 \pm 0.8\right)$, and low or negligible in the outer ria $\left(\mathrm{EF}_{\mathrm{Pb}}=1.5 \pm 1.0\right)$. On the other hand, $\mathrm{Zn}$ contamination is considerable in the inner $\left(\mathrm{EF}_{\mathrm{Zn}}=4.3 \pm 1.0\right)$ and middle ria $\left(\mathrm{EF}_{\mathrm{Zn}}=4.9 \pm 0.8\right)$ and moderate in the outer part $\left(\mathrm{EF}_{\mathrm{Zn}}=2.1 \pm 0.2\right)$. With respect to $\mathrm{Cd}$ in Ferrol, a decrease in concentrations was found from the inner to the outer ria. Background values estimated for the Corme-Laxe Ria helped us to calculate the EF, resulting in a very high Cd contamination in the inner Ferrol Ria (EF $>6$ ), considerable in the middle ria and moderate in the outer ria.

The presence of metal contamination in sediments from the Ferrol Ria compared with those from the Corme-Laxe Ria is not only due to the higher anthropogenic impact, which is significant in Ferrol (Cobelo-García et al., 2004), but also to the morphological characteristics of the ria. The higher fresh-water discharge and the wide, open mouth to the ocean favours the dispersion and flushing of contaminants. The semi-enclosed shape of the populated and industrial Ferrol Ria, connected to the ocean by a narrow channel, enhances the entrapment of contaminants within the bay. Moreover, the Corme-Laxe Ria is close to the summer upwelling events that occur off Cape Finisterre (Prego and Bao, 1997), favouring the renewal of the ria water, whereas this is of lesser importance in the Ferrol Ria since it is distant from the upwelling detected at Cape Prior (Prego and Varela, 1998).

The results obtained show that the Corme-Laxe Ria can be used as a good reference to study metal concentrations and contamination of the 18 Galician rias. The null or scarce anthropogenic impact in the sediments of this ria can be attributed to the scarce anthropogenic activities and its inherent morphological characteristics that favour the flushing of contaminants and water renewal. The Ferrol Ria represents the opposite case: a semi-enclosed embayment with an important urban and industrial impact, trapping contaminants within the bay. From the metal concentrations found in the surface sediments, this ria can be defined as contaminated in $\mathrm{Cd}, \mathrm{Cu}, \mathrm{Pb}$ and $\mathrm{Zn}$ in the middle and inner parts.
2003; tabla 3), la contaminación en Ferrol se puede definir en base al número de veces que se excede la concentración natural (factor de enriquecimiento, FE; Hakanson, 1980). Así, la contaminación por $\mathrm{Cu}$ es considerable $(3<\mathrm{FE}<6)$ en las partes interna y media $\left(\mathrm{FE}_{\mathrm{Cu}}=4.8 \pm 3.3\right.$ y $5.5 \pm 1.4$, respectivamente) y moderada $(1<\mathrm{FE}<3)$ en la externa $\left(\mathrm{FE}_{\mathrm{Cu}}=1.7 \pm 0.6\right)$. La contaminación por $\mathrm{Pb}$ es moderada en las partes interna $\left(\mathrm{FE}_{\mathrm{Pb}}\right.$ $=1.8 \pm 0.5)$ y media $\left(\mathrm{FE}_{\mathrm{Pb}}=2.8 \pm 0.8\right)$ y baja o nula en la parte externa $\left(\mathrm{FE}_{\mathrm{Pb}}=1.5 \pm 1.0\right)$. Por otra parte, la contaminación por $\mathrm{Zn}$ es considerable en las partes interna $\left(\mathrm{FE}_{\mathrm{Zn}}=4.3 \pm 1.0\right) \mathrm{y}$ media $\left(\mathrm{FE}_{\mathrm{ZN}}=4.9 \pm 0.8\right)$ y moderada en la parte externa $\left(\mathrm{FE}_{\mathrm{Zn}}\right.$ $=2.1 \pm 0.2)$. Con respecto al Cd, en Ferrol se observa una disminución en sus concentraciones de la parte más interna hacia el mar. Los valores de fondo estimados para Corme-Laxe permiten calcular unos FE que definen la contaminación por Cd en la ría de Ferrol como muy alta ( $\mathrm{FE}>6)$ en la zona interna, considerable en la media y moderada en la externa.

La contaminación por metales pesados en la ría de Ferrol en comparación con la de Corme-Laxe se debe no sólo a los aportes contaminantes, que son importantes en el caso de Ferrol (Cobelo-García et al., 2004), sino también a las características morfológicas de las rías. El mayor caudal fluvial, la forma ancha y las dimensiones en la boca de la ría de CormeLaxe deben favorecer en gran medida la dispersión de la contaminación hacia el mar abierto, mientras que lo opuesto debe ocurrir en la poblada e industrial ría de Ferrol al estar conectada a la plataforma continental por un estrecho canal. Incluso en verano, cuando la depuración de una ría podría ser menor al ser una época estival, la renovación del agua en Corme-Laxe debe verse favorecida por su proximidad al corazón del afloramiento de Finisterre (Prego y Bao, 1997), mientras que Ferrol queda normalmente aislado del afloramiento detectado en Cabo Prior (Prego y Varela, 1998).

A partir de los resultado obtenidos, la ría de Corme-Laxe constituye una buena referencia para las 18 rías gallegas en cuanto al contenido natural de metales. La escasa o nula influencia antropogénica presente en su compartimento sedimentario puede atribuirse, además de a la escasa actividad antropogénica, a sus características morfológicas que abren esta ría al intercambio con el océano. Por lo contrario, una ría semicerrada con un amplio asentamiento urbano e industrial como Ferrol acumula fácilmente contaminantes en sus sedimentos. A partir de los valores obtenidos en los sedimentos superficiales de la ría de Ferrol, se puede decir que esta ría está contaminada en sus partes media e interna por los metales pesados medidos: $\mathrm{Cd}, \mathrm{Cu}, \mathrm{Pb}$ y $\mathrm{Zn}$.

\section{Agradecimientos}

Nuestro reconocimiento a la colaboración de la tripulación del B/I CSIC Mytilus y a la asistencia prestada en los muestreos y tratamiento de las muestras por parte de Monserrat Martínez y Daniel Caride y en los análisis por Carmen Tubio. También agradecemos al Ministerio de Ciencia y Tecnología el apoyo financiero (Beca FPI) a ACG. Este artículo es una contribución a los proyectos FEDER-CICYT titulados "Procesos 


\section{Acknowledgements}

The authors thank the crew of the R/V CSIC Mytilus for their kind cooperation, Monserrat Martínez and Daniel Caride for their assistance during the sampling and handling, and Carmen Tubio for the chemical analysis. The first author thanks the Spanish Ministry of Science and Technology for financial support (FPI grant). This study is a contribution to the FEDER-CICYT projects "Procesos biogeoquímicos en la ría de Ferrol: Origen de su fertilización por sales nutrientes y variación espacial e histórica de metales en el sedimento" (ref. IFD97-0479-CO3-02), and "Hidrodinámica e hidroquímica del sistema integrado cuenca del río Anllóns-ría de Laxe: Situaciones estacionales y respuesta a eventos de avenidas extraordinarias” (ref. HID99-0699).

\section{References}

Balci, A. (1999). Recent sediments as a trap for the trace metals in a estuarine and coastal marine environment. Fresenius Environ. Bull., 8: 65-71.

Bermejo-Barrera, P., Barciela-Alonso, C., Aboal-Somoza, M. and Bermejo-Barrera, A. (1994). Slurry sampling for the determination of lead in marine sediments by electrothermal atomic absorption spectrometry using palladium-magnesium nitrate as chemical modifier. J. Anal. At. Spectrom., 9: 469-475.

Carballeira, A., Carral, E., Puente, X. and Villares, R. (2000). Regional-scale monitoring of coastal contamination. Nutrients and heavy metals in estuarine sediments and organisms on the coast of Galicia (northwest Spain). Int. J. Environ. Pollut., 13: 534-572.

Carral, E., Puente, X., Villares, R. and Carballeira, A. (1995). Background heavy metal levels in estuarine sediments and organisms in Galicia (northwest Spain) as determined by modal analysis. Sci. Total Environ., 172: 175-188.

Cobelo-García, A. and Prego, R., (2003). Heavy metal sedimentary record in a Galician ria (NW Spain): Background values and recent contamination. Mar. Pollut. Bull., 46: 1253-1262.

Cobelo-García, A., Prego, R. and Labandeira, A. (2004). Land inputs of trace metals, major elements, particulate organic carbon and suspended solids to an industrial bay of the NE Atlantic. Water Res., 38: 1753-1764.

Doherty, G.B., Coomans, D. and Brunskill, G.J. (2000). Modelling natural and enhanced trace metal concentrations in sediments of Cleveland Bay, Australia. Mar. Freshwater Res., 51: 739-747.

EPA (1996). Method 3052: Microwave assisted acid digestion of siliceous and organically based matrices. www.epa.gov/epaoswer/ hazwaste/test/3052.pdf.

Hakanson, L. (1980). An ecological risk index for aquatic pollution control. A sedimentological approach. Water Res., 14: 975-1001.

Helland, A. (2001). The importance of selective transport and sedimentation in trend monitoring of metals in sediments. An biogeoquímicos en la ría de Ferrol: origen de su fertilización por sales nutrientes y variación espacial e histórica de metales en el sedimento" (ref. IFD97-0479-CO3-02) e "Hidrodinámica e hidroquímica del sistema integrado en la cuenca del río Anllóns-Ría de Laxe: situaciones estacionales y respuesta a eventos de avenidas extraordinarias” (ref. HID99-0699).

Traducido al español por los autores.

example from the Glomma Estuary. Water, Air, Soil Pollut., 126: 339-361.

Hölemann, J.A., Schirmacher, M., Kassens, H. and Prange, A. (1999). Geochemistry of surficial and iceratted sediments from the Laptev Sea (Siberia). Estuar. Coast. Shelf Sci., 49: 45-59.

Hornberger, M.I., Luoma, S.N., van Geen, A., Fuller, C. and Anima, R. (1999). Historical trends of metals in the sediments of San Francisco Bay, California. Mar. Chem., 64: 39-55.

Labandeira, A.M. (2003). Metales pesados en el sedimento superficial de un sistema costero: El estuario del río Anllóns y la ría de Corme-Laxe. Tesis de licenciatura, Universidad de Vigo, 104 pp.

Lueiro, X. y Prego, R. (1999). La ría de Ferrol: Revisión de su conocimiento. Monogr. Quím. Oceanogr., I: 1-30.

Millward, G.E. and Glegg, G.A (1997). Fluxes and retention of trace metals in the Humber Estuary. Estuar. Coast. Shelf Sci., 44: 97-105.

Naidu, AS., Blanchard, A., Kelley, J.J., Goering, J.J., Hameed, M.J. and Baskaran, M. (1997). Heavy metals in Chukchi Sea sediments as compared to selected Circum-Arctic shelves. Mar. Pollut. Bull., 35: 260-269.

Prego, R. and Fraga, F. (1992). A. simple model to calculate the residual flows in a Spanish ria. Hydrographic consequences in the ria of Vigo. Estuar. Coast. Shelf Sci., 34: 603-615.

Prego, R. and Bao, R. (1997). Upwelling influence on the Galician coast: Silicate in shelf water and underlying surface sediments. Cont. Shelf Res., 17: 307-318.

Prego, R. and Varela, M. (1998). Hydrography of the Artabro Gulf in summer: western coastal limit of Cantabrian seawater and windinduced upwelling at Prior Cape. Oceanol. Acta, 21: 145-155.

Prego, R. and Cobelo-García, A. (2003). Twentieth century overview of heavy metals in the Galician rias (NW Iberian Peninsula). Environ. Pollut., 121: 425-452.

Sari, E. and Cagatay, M.N. (2001). Distributions of heavy metals in the surface sediments of the Gulf of Saros, NE Aegean Sea. Environ. Int., 26: 169-173.

Wedepohl, K.H. (1991). The composition of the upper Earth's crust and the natural cycles of select metals. In: E. Merian (ed.), Metals and their Compounds in the Environment. Part I. Chapter 1.1., pp. 3-17. VCH.

Zwolsman, J.J.G., van Eck, G.T.M. and Burger, G. (1996). Spatial and temporal distribution of trace metals in sediments from the Scheldt Estuary, south-west Netherlands. Estuar. Coast. Shelf Sci., 43: 55-79. 